Egyptian J. Anim. Prod. (2012) 49(2):219-231

\title{
PROTEIN-SPARING EFFECT OF DL-METHIONINE AND CHOLINE SUPPLEMENTATION OF LOW-PROTEIN DIETS ON PRODUCTIVITY IN LAYING HENS
}

\section{I.I. Omara}

\author{
Division of Poultry Nutrition, Department of Animal Production, Faculty of Agriculture, Cairo \\ University, Giza, Egypt
}

\section{SUMMARY}

An experiment was conducted to investigate the sparing effect of Dl-methionine and choline in lowprotein diets offered to laying hens on productivity performance, egg quality, immune response, and nutrients digestibility; and in reducing pollution of the environment due to lowering ammonia nitrogen in the excreta. Two levels of dietary protein (18 and 15\% CP) were investigated in laying hens. The control diet contained $18 \% \mathrm{CP}, 0.40 \%$ methionine and $400 \mathrm{mg}$ choline $/ \mathrm{kg}$. The experimental diets that contained 15\% CP were supplemented with two levels of methionine, 0.30 and $0.40 \%$, and three levels of choline, 400, 800 , and $1600 \mathrm{mg} / \mathrm{kg}$ diet, for a total of six dietary treatments. The control and six experimental diets were studied in Seven hundred Bovans White hens, at 27-week of age. Each experimental group consisted of 100-hens, which were sub-divided into 4 replicates of 25-hens each.

Results showed that a significant increase in hen-day egg production $(P<0.0001)$ and egg weight $(P<0.05)$ in hens fed diet that contained $15 \%$ protein, $0.30 \%$ methionine and $1600 \mathrm{mg}$ choline/kg. Hens receiving the low-CP diets consumed significantly more $(P<0.05)$ feed than those receiving the control diet. Moreover, the combination of $15 \%$ protein at different levels of methionine and choline supplementation significantly improved $(P<0.0001)$ feed conversion ratio and protein conversion ratio compared to the control group which contained 18\% CP. However, average live body weight gain was not affected by protein, methionine and choline interactions.

Shell thickness and serum total immunoglobulin titers were significantly improved with all the diets that contained 15\% CP at different levels of methionine and choline, compared to the control group. Nevertheless, no significant effects on egg shell weight and Haugh unit were observed due to protein, methionine and choline combinations. However, there was a significant increased $(P<0.0001)$ in yolk and albumen weight due to interaction among low-protein diets which contained 0.30 or $0.40 \%$ methionine, and 800 or $1600 \mathrm{mg}$ choline $/ \mathrm{kg}$. It was also noted that crude protein digestibility, nitrogen excreted (NE) and nitrogen balance (NB) were significantly improved by dietary protein, methionine, choline, or their interaction; while, dry matter, organic matter, ether extract, crude fiber and nitrogen free extract digestibilities were not affected by studied same nutrients. It appears that laying hens fed low protein diet supplemented with methionine excreted less nitrogen in their excreta, hence less pollution to the environment compared to the group fed control diet. The economic study was affected by different combinations of protein, methionine and choline levels, where increasing level of choline supplementation to the low-protein and low-methionine diets increased economic efficiency.

In conclusion, the dietary combination of $15 \% \mathrm{CP}, 0.30$ methionine, and $1600 \mathrm{mg}$ choline/kg diet was adequate in meeting the birds dietary requirements, without adversely affecting hen's productivity performance, egg quality, immune response and nutrient digestibility, and with the added benefit of reducing environmental contamination with ammonia nitrogen. Also, choline can spare part of the methionine supplementation in layer's diets, and was as effective in improving performance, egg quality and immunity of the birds.

Keywords: Protein, methionine, choline, sparing effect, performance, egg quality, immunity, digestibility

\section{INTRODUCTION}

To optimize production cost, the hen's diets must contain adequate quantities of all nutrients needed, particularly protein (CP). In contrast, it is generally known that providing high dietary protein to animals reduces efficiency of protein utilization and increases heat production that is a major cause of heat stress in tropical zone; while limiting protein consumption and adding synthetic DLmethionine and L-lysine can improve the protein utilization and production performance of the hens (Bunchasak and Silapasorn, 2005 and Narváez-Solarte et al., 2005).

Moreover, efficiency in egg production is also dependent on several factors such as composition, digestibility or availability of amino acids in the diet (Narváez-Solarte et al., 2005). Feeding low dietary protein with

Issued by The Egyptian Society of Animal Production 
balanced amino acids composition was reported to be important to minimize heat stress in tropical area (Bunchasak and Silapasorn, 2005). It also reduces intestinal disorders, level of nitrogen excretion and production cost (Leeson et al., 2001 and Coon, 2004).

Methionine (Met) is the first limiting amino acid in poultry diets based on soybean meal. Methionine functions as a key intermediate in methyl group transfer, known as transmethylation. Providing adequate quantity of methionine is necessary for most practical diets in order to obtain optimum performance. Therefore, it is common practice to supplement diets with synthetic methionine source such as DL-methionine (Liu et al., 2004). Cortes et al. (2001) indicated that supplementation of hen diets with methionine resulted in improved egg production, egg weight and feed conversion ratio.

Choline $(\mathrm{CHO})$ is an essential nutrient for the poultry. One of its functions is to furnish methyl groups, similar to methionine (Harms and Russell, 2002). Choline has long been used as a vitamin supplement for poultry diets. Numerous studies reported the interrelationship between $\mathrm{CHO}$ and Met as donors of methyl groups, with variable results (Garcia-Neto et al., 2000 and Pillai et al., 2006).

Most commercial poultry diets are deficient in methionine, so there is a need for supplemental Met in poultry diets. Thus, continued evaluation of SAA metabolism is an important part of working toward optimum diet formulation. In particular, interrelationships of dietary choline, betaine, methionine, and cysteine need to be further explored in poultry at the metabolic level. Because of the liver's essential and largely unique role in SAA metabolism, it is appropriate to focus on the impact of diet on SAA metabolism in the liver (Pillai et al., 2006). Hence, objective of this experiment was to investigate the influence of dietary levels of protein, methionine, choline, or the combination of these nutrients on performance of laying hens, including egg quality, immunity response, nutrients digestibility and economic efficiency. Therefore, a study was conducted to determine the best levels of methionine and choline in low protein diets to achieve sparing effect to realize optimum performance in laying hens and minimize the production cost.

\section{MATERIALS AND METHODS}

Seven hundred Bovans White hens were used in this experiment. The birds were 27weeks of age, and the study continued for 4 periods, each lasted for 28-days. Hens were randomly divided into 7-groups of 100-hens in 4 replicates of 25-hens each. Hens were kept in clean and fumigated cages of wire floored batteries in closed system house. Feed and water were offered ad-libitum throughout the experimental period (16-weeks) from 27- to 42-weeks of age, under a total of 16-hours light per day regimen.

The experimental diets and their chemical composition are presented in Table (1). The control diet provided $18 \%$ CP, $0.40 \%$ methionine and $400 \mathrm{mg}$ choline $/ \mathrm{kg}$. The experimental diets were designed to contain lower CP level, $15 \%$, was supplemented with either 0.40 or $0.30 \%$ methionine. Each of the methionine level was provided with choline at three level, 400, 800 and $1600 \mathrm{mg} / \mathrm{kg}$ of the diet. Methionine and choline were added as DL-methionine (99\% methionine) and choline chloride $(60 \%$ choline), respectively. The experimental diets were formulated to cover the nutrient requirements according to the recommended allowances of the breed (NRC, 1994).

All the birds in each treatment were weighted at the beginning (initial live body weight) and at the end of experimental period (final live body weight) to calculated body weight gain. The daily feed consumed per hen and hen-day egg production percentage was calculated every four weeks interval during the experimental period. Eggs were collected and weighted every 4-weeks during the experimental periods (16-weeks). Records of egg production, egg weight and feed consumption were used to calculate feed conversion ratio (FCR) and protein conversion ratio (PCR) were calculated as gram feed or protein consumption per day per hen divided by gram egg mass per day per hen, respectively. Egg shell thickness was determined using a dial pipe gauge digital. Haugh units were calculated based on the height of albumen, determined by a micrometer, and egg weight according to (Eisen et al., 1962). Serum total immunoglobulin titres were determined according to Zipp et al. (1983). Proximate analysis of the feed and dried excreta were done following the methods of (A.O.A.C., 1990). Faecal nitrogen was determined according to Jakobsen et al. (1960). To determine the economic efficiency of egg production, the amount of feed consumed during the entire experimental period and the total eggs produced per treatment were considered. The price of experimental diets was calculated according to the price of local market of DL-methionine and choline chloride as well as the prices of the ingredients at the time of conducting the experiment. 
Data were statistically analyzed using the General Linear Model procedures (GLM) described by (SAS Institute, 2004), and applying the following model:

$\mathbf{Y}_{\mathrm{ijkl}}=\boldsymbol{\mu}+\mathbf{P}_{\mathrm{i}}+\mathbf{M}_{\mathrm{j}}+\mathbf{C}_{\mathrm{k}}+(\mathbf{P M C})_{\mathrm{ijk}}+\mathbf{e}_{\mathrm{ijkl}}$

where, $\mathbf{Y}_{\mathbf{i j k l}}$ is the measured parameter, $\boldsymbol{\mu}$ is the overall means, $\mathbf{P}_{\mathbf{i}}$ is the protein levels effect, $\mathbf{M}_{\mathbf{j}}$ is the methionine levels effect, $\mathbf{C}_{\mathbf{k}}$ is the choline levels effect, (PMC) $)_{\mathrm{ijk}}$ is the interaction among protein, methionine and choline effect, and $\mathbf{e}_{\mathbf{i j k l}}$ is the random error term. Differences among treatments were tested using Duncan's multiple range test (Duncan, 1955) and differences were significant at $(\mathrm{P} \leq 0.05)$.

\section{RESULTS AND DISCUSSION}

Percentage hen-day egg production was significantly $(\mathrm{P}<0.05)$ affected, mainly by protein, methionine and choline levels (Table 1). This result agree with the finding of Babiker et al. (2010). Moreover, there was significant difference $(\mathrm{P}<0.0001)$ in egg production due to protein $\mathrm{x}$ methionine $\mathrm{x}$ choline interaction, where hens fed dietary $15 \%$, CP incorporated with $0.30 \%$ methionine, and $1600 \mathrm{mg}$ choline/kg (T6) recorded the highest value $(92.93 \%)$, while, hens fed dietary $15 \%, \mathrm{CP}$ incorporated with $0.40 \%$ methionine, and $400 \mathrm{mg}$ choline $/ \mathrm{kg}$ (T1) gave the least value $(87.94 \%)$. It is clear that low-CP + methionine diets with various levels of choline improved egg production compared to control group. Therefore, the low-CP level with methionine and choline supplementations was adequate and did not adversely affect on egg production and excess protein supplementation did not improve egg production in comparison with the tested diets.

The lowest level of methionine was adequate with added choline and did not adversely affect egg production. Furthermore, increasing methionine level in the diet of laying hens had no beneficial effect on egg production $(\mathrm{P}>0.05)$. These results agreed with that of Bunchasak and Silapasorn (2005) who reported that low-CP $14 \%$, with $0.44 \%$ Met supplementation was adequate to improve henday egg production compared to control group (16\% CP; 0.38\% Met). Silpasorn et al. (2003) showed that egg production was significantly improved when methionine $0.44 \%$ was supplemented to laying hen diets. Harms et al. (1999) obtained a significant $(\mathrm{P}<0.05)$ increase in egg production when $878 \mathrm{mg}$ choline $/ \mathrm{kg}$ was added to the diet containing $0.33 \%$ methionine.

In contrast, Poosuwan et al. (2010) reported that egg production of hens fed $18 \%$ CP diet were significantly higher than those of the $14 \%$ CP group. Acikgoz et al. (2003) showed that egg production was significantly improved when methionine was supplemented to laying hen diets up to $0.44 \%$. Dänicke et al. (2006) found that increasing the choline supplementation in the diets for up to 4000 $\mathrm{mg} / \mathrm{kg}$ did not influence egg production.

The differences in egg weights $(\mathrm{g})$ were not significant $(\mathrm{P}>0.05)$ due to either protein, methionine or choline levels ( Table 2). These results were confirmed by Zeweil et al. (2011) they found that egg weight were not significantly $(\mathrm{P}>0.05)$ affected by protein levels (12, 14 and 16\% CP). Novak et al. (2004) and Amaefule et al. (2004) they reported that methionine supplementation $(0$ and $0.10 \%$ ) of laying hen diets did not affect $(\mathrm{P}>0.05)$ egg weight. Dänicke et al. (2006) observed that there were no significant $(\mathrm{P}>0.05)$ differences among hens they received diets containing choline level up to 4000 $\mathrm{mg} / \mathrm{kg}$. However, the effect of interaction among protein, methionine and choline on egg weight was significant $(\mathrm{P}<0.05)$. Keshavarz (2003) who reported that increasing the concentration of several nutrients in the diet increased egg weight. These nutrients include methionine and choline or combinations of related nutrients. In literature, the sparing effect of choline on methionine depends on dietary methionine level (Attia et al. 2005). Contrary to that, egg weight was significantly $(\mathrm{P}<0.01)$ influenced by the interaction of both $\mathrm{CP}$ and dietary TSAA levels (Mohammed and Samie, 2007). Koreleski and Świątkiewicz (2011) reported that methionine supplementation significantly increased egg weight and daily egg mass per hen. The inconsistency in response could be due to low sensitivity, large variation in experimental birds, and different statistical methods used to analyze the data (Liu et al., 2004).

A significant effect on the amount of feed consumed ( $\mathrm{g} / \mathrm{hen} /$ day) was noted due to protein levels (Table 2). Hens receiving the low-CP diets consumed significantly $(\mathrm{P}<0.05)$ more feed than those receiving the control diet. Hens increased feed intake to meet their increased nutrients requirement. The results indicated that $14.1 \%$ dietary $\mathrm{CP}$ was the marginal level that caused hens to consume more feed to meet their dietary needs compared with 15.1\% CP (Mohammed and Samie, 2007). However, methionine and choline levels did not effect $(\mathrm{P}>0.05)$ the amount of feed intake. Novak et al. (2004) and Abd-Elsamee (2005) indicated that there were no significant differences $(\mathrm{P}>0.05)$ in feed intake of laying hens due to difference in dietary levels of methionine. Also, Dänicke et al. (2006) reported that there were no significant differences $(\mathrm{P}>0.05)$ in feed intake among hens received diets containing choline 
levels up to $4000 \mathrm{mg} / \mathrm{kg}$. However, highly significant effect $(\mathrm{P}<0.0001)$ was noted on feed intake due to interaction of protein, methionine with choline. The average values of feed intake ranged between 112.75 and $117.14 \mathrm{~g} / \mathrm{hen} /$ day for hens fed the control group and others fed dietary $15 \%$ CP incorporated with $0.30 \%$ methionine and 800 $\mathrm{mg}$ choline/kg (T5), respectively. This variation in feed intake may be due to imbalance in amino acids intake.

Two types of imbalance may be caused by the addition of a relatively small quantity of an amino acid to a low-CP diet, which result in providing an incomplete mixture of amino acids in the feed (D'Mello, 1994). Moreover, Keshavarz and Jackson (1992) and Penz and Jensen (1991) reported that decreasing protein level with methionine supplementation in poultry diets usually did not depress feed intake. Humphrey and Klasing (2004) and Poosuwan et al. (2010) reported that poultry feed which were deficient in protein or methionine did not show any depression $(\mathrm{P}>0.05)$ of feed intake. This indicates that level of feed intake may depend on degrees of amino acid balance in diet. In current study, supplementing methionine in low-CP diet may have prevented negative effect of amino acids imbalance on feed consumption.

Bunchasak and Silapasorn (2005), and Harms et al. (1990) noticed that the addition of $878 \mathrm{mg}$ choline $/ \mathrm{kg}$ diet, with $0.33 \%$ supplemental methionine, significantly $(\mathrm{P}<0.05)$ increased feed consumption. They also reported that hens had responded to choline supplementation of a corn-soybean diet marginal in methionine content. On the other hand, Wideman et al. (1994) suggested that depression of feed intake is a highly sensitive marker to excessive amino acid supplementation. Diets supplemented with $0.10 \%$ DL-methionine had significantly reduced feed intake. The precise mechanisms responsible for the negative effects of excess amino acids on feed intake remains unclear, although the obtained results indicate that neither the sulfur content nor the presence of an amino nitrogen group are critical in that respect.

A significant decreased $(\mathrm{P}<0.0001)$ in daily protein intake due to feeding laying hens the diets containing $15 \% \mathrm{CP}$ was noted when compared to the control diet containing $18 \%$ CP (Table 2). This indicates that protein intake per hen per day was significantly decreased when low-CP level was included in the diets. This could be attributed to the different amounts of feed consumed which increased as dietary protein level decreased in the diet compared to control diet.
Dilger et al. (2007) found that feed intake increased $(\mathrm{P}<0.01)$ when $300 \mathrm{mg} / \mathrm{kg}$ choline was added to the choline-free basal diet. Moreover, a slightly significant $(\mathrm{P}<0.05)$ decrease in daily protein intake was observed as dietary choline level increased in the diet up to $1600 \mathrm{mg} / \mathrm{kg}$. However, no significant differences between methionine levels in the daily protein intake were observed. In the present study, the interaction among dietary protein, methionine and choline showed a significant difference $(\mathrm{P} \leq 0.0001)$ in daily protein intake, the highest value of daily protein intake $(20.30 \mathrm{~g} / \mathrm{hen} /$ day $)$ was recorded for birds fed the control group, while the lowest values (17.14 and $17.20 \mathrm{~g} / \mathrm{hen} /$ day) obtained for bids fed dietary $15 \%$, CP incorporated with $0.30 \%$ met, and $1600 \mathrm{mg}$ choline/kg (T6) and others fed dietary $15 \%$, CP incorporated with $0.40 \%$ met, and 1600 $\mathrm{mg}$ choline/kg (T3), respectively. This result agrees with that of Poosuwan et al. (2010) reported that protein intake of hens fed $18 \%$ CP diet were significantly higher than those of the $14 \%$ CP group. Also, Bunchasak and Silapasorn (2005) observed that the control group $(16 \% \mathrm{CP})$ had highest protein intake, at the same time as protein intake of the low-CP (14\%) diet with $0.26 \%$ Met was the lowest $(\mathrm{P}<0.01)$.

No significant differences due to the main effect of protein, methionine and choline on feed conversion ratio (Table 2). Zeweil et al. (2011) reported that different levels of protein $(12,14$ and $16 \% \mathrm{CP})$ not significantly affected FCR. Amaefule et al. (2004) showed that the supplementation $0.10 \%$ methionine did not affect FCR. Rao et al. (2001) found that the supplementation 0,750 and $1520 \mathrm{mg}$ choline $/ \mathrm{kg}$ did not influence the efficiency of feed utilization. However, the combination among protein, methionine and choline affected significantly $(\mathrm{P}<0.0001)$ on FCR. The diet containing low-CP, $0.30 \%$ methionine with $1600 \mathrm{mg}$ choline/kg gave the better FCR compared to other groups. These results due to two reasons, the different amounts of feed consumed and egg production and sparing effect of supplementation sulfur amino acid (methionine) and vitamin (choline) to low-CP diets $(15 \%)$ which improved FCR. Mohammed and Samie (2007) found that FCR was significantly $(\mathrm{P}<0.01)$ influenced by the interaction of both $\mathrm{CP}$ and dietary TSAA levels. Tsiagbe et al. (1992) who reported that the best value of FCR was obtained with combination of $0.427 \%$ methionine and added choline at level of $1280 \mathrm{mg} / \mathrm{kg}$ to laying hen diets. Nevertheless, Koreleski and Świątkiewicz (2011) reported that methionine supplementation significantly improved feed conversion per $\mathrm{kg}$ of eggs. The interaction 
between protein and methionine revealed that FCR did not significantly affect by the interaction between protein and methionine levels. Dänicke et al. (2006) observed that feed-to-egg mass ratio which was significantly reduced by choline addition up to $4000 \mathrm{mg} / \mathrm{kg}$.

The best value of protein conversion ratio (PCR) was noticed with all diets containing $15 \%$ CP with different levels of sulfur amino acid (methionine) and vitamin (choline) compared to the control group which containing 18\% CP (Table 2). This is may be due to feed intake was affected by dietary protein level. Moreover, the addition of choline $1600 \mathrm{mg} / \mathrm{kg}$ significant improved $(p<0.05)$ PCR. Inversely, methionine level did not significant on PCR. The significant interaction revealed that diet containing $15 \%$ $\mathrm{CP}, 0.30 \%$ methionine and $1600 \mathrm{mg}$ choline $/ \mathrm{kg}$ (T6) improved PCR compared to control diet. The significant differences in PCR among experimental treatments were supported by the findings of Poosuwan et al. (2010) reported that the hen diets containing 14\% CP improved protein conversion ratio than diets containing $18 \% \mathrm{CP}$.

Average live body weight gain was significantly $(\mathrm{P}<0.05)$ affected by $\mathrm{CP}$ or methionine levels. However, not affected $(\mathrm{P}>0.05)$ by choline levels or their interactions. Hens received $18 \% \mathrm{CP}$ or $0.4 \%$ methionine diets gained more weight than those received $15 \%$ CP or $0.30 \%$ methionine diets. These results might be due to the adequacy of protein and methionine in the diets to maintain body weight. Poosuwan et al. (2010) found that dietary protein levels ( $18 \%$ vs. $14 \%$ CP) significantly affect on hens body weight gain, which increased by protein levels increased (64.19 vs. 53.23g, respectively). Moreover, Oke et al. (2003) suggested that diet containing $16 \% \mathrm{CP}$ and $2750 \mathrm{kcal} \mathrm{ME} / \mathrm{kg}$ is ideal for optimum body weight gain for laying hens probably because the diet contains a good balance between energy and protein. Harms and Russell (2003) noted that the loss of body weight was reduced as the level of methionine was increased up to $0.38 \%$. Moreover, ElHusseiny et al. (2005) who reported that the combination between methionine and choline levels up to $0.50 \%$ and $900 \mathrm{mg} / \mathrm{kg}$, respectively of laying hen diets did not affect $(\mathrm{P}>0.05)$ on body weight gain. Augspurger. et al. (2005) who found that supplementation of methionine increased $(\mathrm{P}<0.05)$ weight gain of chicks fed methionine-deficient, cholineadequate diets. The previous findings were not agreements with Amaefule et al. (2004) who found that body weight gain did not differ $(\mathrm{P}>0.05)$ among treatments which containing methionine from 0.289 to $0.422 \%$. Dilger et al. (2007) reported that weight gain increased
$(\mathrm{P}<0.01)$ when $300 \mathrm{mg} / \mathrm{kg}$ choline was added to the choline-free basal diet.

Shell thickness was significantly $(\mathrm{P}<0.05)$ affected by protein, methionine or choline levels (Table 3). Moreover, a significant differences were observed in shell thickness due to protein $\mathrm{x}$ methionine $\mathrm{x}$ choline interaction and the values of shell thickness ranged from 0.383 to $0.449 \mu \mathrm{m}$ for hens fed control and T6 diet, respectively. Therefore, all experimental diets from $\mathrm{T} 1$ to $\mathrm{T} 6$ which formulated to contain low-CP (15\%) with methionine and choline supplementation improved $(\mathrm{P}<0.05)$ egg shell thickness compared to control diet. The eggshell is formed during the passage of the egg through the oviduct, where the various layers of the egg shell are assembled sequentially (Novak et al., 2004). Egg shell thickness was significantly $(\mathrm{P}<0.01)$ improved when methionine at 0.30 or $0.38 \%$ was added to $14 \%$ low-CP diets than the control group which containing $16 \% \mathrm{CP}$ and $0.38 \%$ methionine (Bunchasak and Silapasorn, 2005).

On the other hand, the thickness was slightly decreased in the highest level of methionine group $(0.40 \% \mathrm{Met})$. In this case, the tendency for the negative effect of high supplementing methionine $(0.40 \%)$ may be due to the fact that egg shell thickness and egg shell weight reduce with increase in egg size (Roland, 1988). Keshavarz and Nakajima (1993) indicated that the reason for reduced shell quality is due to increased egg size, distribution a constant amount of shell components over a larger egg. Another reason is that, in general, the foundation of a shell consists of a protein matrix, and it may be possible that increasing the TSAA intake may influence protein synthesis of shell membranes (Novak et al., 2004)

Loss of bone density, with resultant deformities and fractures, associated with old age is a major concern. Bone density loss, or osteoporosis, is a definite health issue that can be managed and prevented if one understands the cause and effect relationship. One of the mechanisms, and the one that gets most of the scientific support, is the reduction in hormone levels associated with aging. There are two kinds of cells found in bone. The osteoclasts are constantly destroying old bone, while osteoblasts are constantly building new bone. It is necessary for these two processes, bone destruction and bone building, to be in balance in order to have solid healthy bones. There are two control mechanisms by which osteoblasts are stimulated to create new bone mass. One is hormonal regulation, and the other is the piezoelectric stimulation of bone growth that comes from exercise. One of the principal factors in the hormonal regulation of bone 
health is a group of hormones that are referred to as the estrogens.

Another contributing factor in the development of osteoporosis is homocysteine. Homocysteine is a metabolite of the amino acid methionine. It has been implicated in several degenerative diseases including heart disease, arteriosclerosis, and osteoporosis. High homocysteine levels cause osteoporosis by the formation of defective bone (protein) matrix. Homocysteine is detoxified into methionine by specific nutrients which are able to donate methyl groups to the homocysteine molecule. These nutrients include folic acid, $\mathrm{B}_{12}, \mathrm{~B}_{6}$, and betaine (trimethylglycine). Over eighteen nutrients are required to build bone. Calcium is the most abundant element in bone, but without the others, new bone cannot be built regardless of how much calcium is available. These nutrients include calcium, phosphorus, magnesium, manganese, zinc, copper, boron, silica, fluorine, vitamins $\mathrm{A}, \mathrm{C}$, $\mathrm{D}, \mathrm{B}_{6}, \mathrm{~B}_{12}, \mathrm{~K}$, folic acid, essential fatty acids, and protein. The body only uses minerals well when they are in a proper balance. An excess of phosphorus, for example, can cause loss of bone calcium and reduced bone mass (Lieberman, 2005).

Keshavarz (2003) reported that reducing dietary protein in combination with reduced dietary methionine and choline improved shell quality. In current study, no significant effects $(\mathrm{P}>0.05)$ on shell weight and Haugh unit, were noted due to main effects of protein, methionine, choline, and combination among these nutrients (Table 3). Wu et al. (2007) reported that no significant effect of dietary protein on shell weight and Haugh unit. Novak et al. (2004) and Amaefule et al. (2004) showed that $0.10 \%$ methionine supplementation to layer diets did not significantly influence egg shell weight and Haugh unit values. Rao et al. (2001) observed that amount of supplemental choline at levels up to $1520 \mathrm{mg} / \mathrm{kg}$ diet did not influence Haugh unit score.

Moreover, Zeweil et al. (2011) reported that the interaction between 12,14 and $16 \%$ crude protein and 1.67, 2.00, 2.37 and $2.75 \%$ methionine of CP did not effect Haugh unit. El-Husseiny et al. (2005) reported that shell weight and Haugh unit were not influenced significantly by dietary methionine up to $0.50 \%$, choline up to $900 \mathrm{mg} / \mathrm{kg}$, and their combinations of laying hen diets. On the other hand, Fraser et al. (1998) suggested that it may be possible that increasing the TSAA intake may influenced shell weight by protein synthesis of shell membranes. Abd-Elsamee (2005) observed that the use of high levels of methionine $(0.49$ and $0.55 \%)$ increased significantly Haugh unit values compared with the control group $(0.42 \%$ methionine).

As shown in Table 3 the weights of egg components (yolk and albumen) were not influenced significantly by protein, methionine and choline levels. However, there was a significant $(\mathrm{P}<0.0001)$ differences in yolk and albumen weight due to interaction among protein, methionine and choline. The average value of the different experimental treatments ranged between 59.14 and 60.50 gm for hens fed T2 and T6, respectively. El-Husseiny et al. (2005) and Dänicke et al. (2006) found that no significant effect $(\mathrm{P}>0.05)$ on yolk and albumen weight due to methionine, choline and interaction between them. Moreover, Harms and Russell (2002) who reported that there were no significant differences in egg content among the hens receiving choline at level up to $1286 \mathrm{mg} / \mathrm{kg}$. In contrast, Harms et al. (2003) found that egg content increased as the level of methionine increased in the diet.

A significant differences in serum total immunoglobulin titres were observed with dietary CP, methionine, choline or interaction among them (Table 3). Moreover, low-CP diets resulted in the highest average of serum titres compared to control group $(18 \% \mathrm{CP})$ which recorded the least value. Concerning the various experimental diets, the values ranged from 9.55 to 10.55 for the control group and T6, respectively. The reason for this discrepancy probably relates to the amounts of oil (fatty acids) in the experimental diets. It seems that both short-term and long-term protein deficiency could alter immunological responses of animals (Poosuwan etal., 2010). Even though, Cheema et al. (2003) reported that weight of lymphoid organs such as spleen, thymus gland or bursa of fabricious was not significantly affected by the depression of dietary protein level. Balnave (2000) reported that serum total immunoglobulin titres decreased with increasing dietary methionine level in laying hen diets. Moreover, Omara and Romeilah (2009) noticed that low methionine level $(0.35 \%)$ improved serum total immunoglobulin titres compared to that obtained at level of $0.40 \%$, but, without significant differences. El-Husseiny et al. (2005) showed that a significant effect of methionine by choline interaction on hen's serum total immunoglobulin titres.

Crude protein digestibility, nitrogen excreted (NE) and nitrogen balance (NB) were significantly affected by dietary protein, methionine, choline or their interaction while, DM, OM, EE, CF and NFE digestibilities not affected $(\mathrm{P}>0.05)$ by dietary previous nutrients (Table 4). Therefore, different CP levels, especially low-CP (15\%) diets which containing 0.30 or $0.40 \%$ methionine levels improved $(\mathrm{P}<0.05)$ the digestion coefficient 
values of all the nutrients and $\mathrm{NE}$ and $\mathrm{NB}$ compared to the control diet (18\% CP ; $0.40 \%$ methionine). The best values were for hens fed T6, and the least values was recorded for birds fed control diet group. Zeweil et al. (2011) indicated that decreasing protein levels from 16 to 14 and $12 \%$ in the diets increased the CP digestibility ( 87.55 and 87.74 to $88.19 \%$, respectively). Therefore, Naulia and Singh (2002) reported that the digestibility of dry matter (DM) and organic matter (OM) were significantly higher $(\mathrm{P}<0.05)$ on $0.323 \%$ methionine level compared to 0.248 and $0.267 \%$ level. Omara and Romeilah (2009) found that $0.35 \%$ methionine deficiency did not significant effect $(\mathrm{P}>0.05)$ on $\mathrm{DM}, \mathrm{OM}$, $\mathrm{EE}, \mathrm{CF}$ and NFE digestibility compared to $0.40 \%$ methionine in hen diets. El-Husseiny et al. (2005) observed that no significant differences $(\mathrm{P}>0.05)$ in nutrients digestibility coefficient (DM, OM, EE and $\mathrm{CF}$ ) due to methionine $\mathrm{x}$ choline interaction on layers.

Excess in dietary protein causes higher nitrogen losses in feaces and contributes to environmental pollution. Reductions of excreta nitrogen play an important role in reducing the level of ammonia emissions from laying hens excreta in poultry house and uric acid in litter which causes many respiratory disorders. Also these reductions reflect positively in reducing environmental nitrogen pollution (Zeweil et al. 2011).

The net revenue and economic efficiency values varied from 23.36-26.99 and 0.75-0.89, respectively (Table 5). The lowest values were recorded for hens fed $\mathrm{T} 1$, while, the highest values were calculated for others fed (T6). Moreover, decreasing the crude protein percentage in layer diet reduced the price of kilogram diet thus, maximizing the net return profitability and relative economic efficiency. The same results were observed with many investigators (Leeson et al., 2001 and Coon, 2004). According to the input-output analysis, the diets containing $12 \%$ crude protein and supplemented with 2.327 and 2.754 Meth.\% of $\mathrm{CP}$ proved to be the most relative economic efficiency diet (115.06 and $115.99 \%$, respectively), as compared to the other diets, decreasing of crude protein in the layer diets from 16 to $12 \%$ decreased the price of $\mathrm{kg}$ feed, which reflected in reduction of the total cost of feed consumed during the experimental period, and supplementation of DL-methionine to layer diets improved the performance of the layer hen through increasing their overall egg mass (Zeweil et al., 2011)

\section{CONCLUSION}

The significant interactions between dietary protein, methionine, and choline in current study reveal that feeding laying hens diet containing $15 \% \mathrm{CP}, 0.30 \%$ methionine and $1600 \mathrm{mg}$ choline $/ \mathrm{kg}$ has improved performance, egg quality, immune response and nutrients digestibility; with positive impact on economy of operation and improved profitability. These positive effects on performance may be attributed to the protein sparing effect of supplementation with the sulfur-containing amino acid (methionine) and the vitamin (choline) when added to low protein diets $(15 \% \mathrm{CP})$. Improved performance of Bovans White hens was evident at peak productivity of 27-42 week of age. An inadequate methionine supply in the diet can be compensated by an increase in choline supplementation. Furthermore, by increasing nitrogen absorption from low-CP diet, excretion of nitrogen in the droppings (excreta) would decrease. Consequently, environmental contamination with nitrogen and its byproducts may be reduced with the ultimate benefit of producing more friendly environment and healthier products.

\section{ACKNOWLEDGMENTS}

The author would like to thanks all the staff members at the Animal Production Islamic Company (APICO) for given our facilities and their great help, co-operation and for funding support of this research.

\section{REFERENCES}

Abd-Elsamee, M.O., 2005. Effect of different levels of methionine and vitamin $\mathrm{E}$ on laying hen performance under heat stress conditions. $3^{\text {rd }}$ International Poultry Conference. 4-7 April 2005 HurghadaEgypt.

Acikgoz, Z., V. Ayhan, K. Ozkan, O. Altan, A. Altan, S. Ozkan and Y. Akbas, 2003. The effects of dietary oil and methionine on performance and egg quality of commercial laying hens during summer season. Archivfur-Geflugelk unde, 67: 204-207.

Amaefule, K.U., G.S. Ojewola and E.C. Uchegbu, 2004. The effect of methionine, lysine and/or vitamin $\mathrm{C}$ (ascorbic acid) supplementation on egg production and egg quality characteristics of layers in humid tropics. Livestock Research for Rural Development. 16 : (9).

Association of Official Agricultural Chemists, 1990. “Official methods of analysis" $15^{\text {th }} \mathrm{Ed}$. Published by the A.O.A.C., Washington, D.C.

Attia, Y.A., R.A. Hassan, M.H. Shehatta and Salwa, B. AbdElHady, 2005. Growth, carcass characteristics, blood serum constituents and immune response of 
roaster type chickens fed diets containing different levels of methionine and betaine. $3^{\text {rd }}$ International Poultry Conference. 4-7 April 2005 Hurghada - Egypt.

Augspurger, N.R., S.C. Scherer, A.T. Garrow and D.H. Baker, 2005. Dietary Smethylmethionine, a component of foods, has choline-sparing activity in chickens. J. Nutr. 135: 1712-1717.

Babiker, M.S., S.A. Abbas, C. Kijora and J. Danier, 2010. The effect of dietary protein and energy levels during the growing period of egg-type pullets on early egg production and egg weight and diminosions in Arid hot climate. Inter.J. of Poult. Sci., 9: 935-943.

Balnave, D,. 2000. Protein and methionine requirements of imported Brown layer strains. A report for the rural industries research and development corporation.

Bunchasak, C. and T. Silapasorn, 2005. Effects of adding methionine in low-protein diet on production performance, reproductive organs and chemical liver composition of laying hens under tropical conditions. Inter. J. of Poult. Sci., 4: 301-308.

Cheema, M.A., M.A. Qureshi and G.B. Havenstein, 2003. A comparison of the immune response of a 2001 commercial broiler with a 1957 random bred broiler strain when fed representative 1957 and 2001 broiler diets. Poult. Sci., 82: 1519 1529.

Coon, C., 2004. The ideal amino acid requirement and profile for broilers, layers and broiler breeders. The American Soybean Association. July, 2004.

Cortes, C.A., P.F.j. Diaz and G.E. Avila, 2001. Performance with the addition of two methionine sources in the diet on laying hens. Veterinaria Mexico. 32: 183-187.

D’Mello, J.P.F., 1994. Amino acid imbalances, antagonisms and toxicities. Page 63-97, In: Amino acids in farm animal nutrition, Edited by J.P.F. D'Mello, CAB International.

Dänicke, S., K. Ueberschär, K. Reese and S. Weigend, 2006. Investigations on the effects of rape oil quality, choline and methionine concentration in diets for laying hens on the trimethylamine content of the eggs, on trimethylamine metabolism and on laying performance. Archives of Anim. Nutr., 60: 57 - 79

Dilger, N.R., A.T. Garrow and D.H. Baker. 2007. Betaine can partially spare choline in chicks but only when added to diets containing a minimal level of choline. J. Nutr., 137: 2224-2228.

Duncan, D.B., 1955. Multiple range and multiple F-tests. Biometrics. 11: 1-42.
Eisen, j.E., B.B. Bohren and E.H. McKean, 1962. The Haugh units as a measure of egg albumen quality. Poult. Sci., 41: 14611468.

El-Husseiny, O.M., A.Z. Soliman, M.O. AbdElsamee and I.I. Omara, 2005. Effect of dietary energy, methionine, choline and folic acid levels on layers performance. Egyptian Poult. Sci. j., 25 (IV): 931-956.

Fraser, A.C., M.M. Bain and S.E. Solomon, 1998. Organic protein matrix morphology and distribution in the palisade layer of egg shells sampled at selected periods during lay. Br. Poult. Sci., 39: 225 - 228.

Garcia-Neto, M., G.M. Pesti and R.I. Bakalli, 2000. Influence of dietary protein level on the broiler chicken's response to methionine and betaine supplements. Poult. Sci., 79:1478-1484.

Harms, H.R. and B.G. Russell, 2002. Betaine does not improve performance of laying hens when the diet contains adequate choline. Poult. Sci., 81: 99-101.

Harms, H.R. and B.G. Russell, 2003. Performance of commercial laying hens fed diets with various levels of methionine. J. Appl. Poult. Res., 12:449-455.

Harms, H.R., E.D. Faria and B.G. Russell, 2003. Evaluation of the suggested requirement of six amino acids for the commercial laying hen. J. of Appl. Anim. Res., 23: 129-138.

Harms, H.R., K.L. Hinton and B.G. Russell, 1999. Energy: methionine ratio formulating feed for commercial layers. J. Appl. Poult. Res., 8: 272-279.

Harms, H.R., N. Ruiz and R.D. Miles, 1990. Research note: conditions necessary for a response by the commercial laying hen to supplemental choline and sulfate. Poult. Sci., 69: 1226-1229.

Humphrey, B.D. and K.C. Klasing, 2004. Modulation of nutrient metabolism and homeostasis by the immune system. World's Poult. Sci. J., 60: 90-100.

Jakobsen, P.E., S.G. Kirston and H. Nelson, 1960. Digestibility trials with poultry. 322 bertning fraforsgs laboratories, udgivet of stants Husdyrbugsudvalg-Kabenha

Keshavarz, K. and E.M. Jackson, 1992. Performance of growing pullets and laying hens fed with low-protein amino acidsupplemented diets. Poult. Sci., 71: 905918.

Keshavarz, K. and S. Nakajima, 1993. Reevaluation of calcium and phosphorus requirement of laying hens for optimum performance and egg shell quality. Poult. Sci., 72: 144-153.

Keshavarz, K., 2003. Effects of reducing dietary protein, methionine, choline, folic acid and vitamin $\mathrm{B}_{12}$ during the late stages 
of the egg production cycle on performance and egg shell quality. Poult. Sci., 82: 14071414.

Koreleski, J. and S. Świątkiewicz, 2011. Effect of methionine and energy level in high protein organic diets fed to laying hens. Ann. Anim. Sci., 10: 83-91.

Leeson, S., J.D. Summers and L.J. Caston, 2001. Response of layers to low nutrient density diets. J. Appl. Poult. Res., 10: 4652

Lieberman, S., 2005. Osteoporosis or Healthy Bones at all Ages. Advanced Health \& Life Extension. http://www.estrogen and folic acid relationship with calcium metabolism.

Liu, Z., A. Bateman, S.S. Sohail, B. Zinner and D.A. Roland, 2004. Statistical sensitivity required to detect any potential difference of bioavailability between DL-methionine and DL-methionine hydroxyl analogue in layers. Inter. J. of Poult. Sci., 3: 697-703.

Mohammed, A.P. and A. Samie, 2007. Sulfur amino acids requirements of laying hens in low protein diets. World Poultry Science Association, Proceedings of the $16^{\text {th }}$ European Symposium on Poultry Nutrition, Strasbourg, France, 26-30 August, pp. 205209

Narváez-Solarte, W., H.S. Rostagno, P.R. Soares, M.A. Silva and L.F.U. Velasquez, 2005. Nutritional requirements in methionine + cystine for white-egg laying hens during the first cycle of production. Inter. J. of Poult. Sci., 4: 965-968.

National Research Council (NRC), 1994. Nutrient Requirements of Poultry. $9^{\text {th }}$ rev. ed. Natl. Acad. Press, Washington, DC.

Naulia, U. and K.S. Singh, 2002. Replacement of dietary groundnut-cake by soybean meal supplemented with DL-methionine on the performance of layer chickens. Indian J. of Anim. Sci., 72: 1173-1176.

Novak, C., H. Yakout and S. Scheidler, 2004. The combined effects of dietary lysine and total sulfur amino acid level on egg production parameters and egg components in Dekalb Delta layin hens. Poult. Sci., 83: 977-984.

Oke, U.K., U. Herbert and A.H. Akinmutimi, 2003. Early lay characteristics and hematology of pearl Guinea fowls as influenced by dietary protein and energy levels. Inter. J. of Poult. Sci., 2: 128-132.

Omara, I.I. and M.R. Romeilah, 2009. Energy and methionine utilization in laying hen diets supplemented with folic acid. Res. J. of Agri. and Biol. Sci., 5(4): 428-444.

Penz, A.M. and S.L. Jensen, 1991. Influence of protein concentration, amino acid supplementation and daily time of access to high-or low-protein diets on egg weight and components in laying hens. Poult. Sci., 70: 2460-2466.

Pillai, B.P., C.A. Fanatico, W.K. Beers, E.M. Blair and L.J. Emmert, 2006. Homocysteine Remethylation in Young Broilers Fed Varying Levels of Methionine, Choline, and Betaine. Poult. Sci., 85:90-95

Poosuwan, K., C. Bunchasak and C. Kaewtapee, 2010. Long-term feeding effects of dietary protein levels on egg production, immunocompetence and plasma amino acids of laying hens in subtropical condition. J. of Anim. Phys. and Anim. Nutr., 94:186-195

Rao, S.U.R., G.S. Sunder, M.R. Reddy, N.K. Praharaj, M.V.L.N. Raju and A.K. Panda, 2001. Effect supplementary choline on the performance of broiler breeders fed on different energy sources. Br. Poult. Sci., 42: 362-367.

Roland, D.A.(1988). Egg Shell Problems: Estimates of incidence and economic impact. Poult. Sci., 67: 1801-1803.

SAS institute, 2004. SAS/STAT User's Guide. SAS Institute Inc., Cary, NC.

Silpasorn, T., C. Bunchasak and S. Atamangkoon, 2003. Effects of methionine supplementation in low protein diet on production, reproductive organs, abdominal fat and liver composition of laying hens raised in closed house system. Proceedings of $41^{\text {st }}$ Kasetsart University Annual Conference, 3-7 February, 2003 subject: Animals and Veterinary Medicine, 385393.

Tsiagbe, V.K., A.E. Harper and M.L. Sunde 1992. A feather-sexed strain of laying hens was more responsive to dietary supplements of choline and methionine than a vent-sexed strain. Poult. Sci., 71: 1271-1276.

Wideman, F.R., C.B. Ford, J.J. Dibner, W.W. Robey and G.A. Yersin 1994. Responses of laying hens to diets containing up to $2 \%$ DL-methionine or equimolar $(2.25 \%) 2$ Hydroxy-4-(methylthio) Butanoic acid. Poult. Sci., 73: 259-267.

Wu, G., M.M. Bryant, A.R. Voitle and A.D. Sr. Roland, 2005. Effect of dietary energy on performance and egg composition in Bovans White and Dekalb White in Phase I. Poult. Sci., 84: 1610-1615.

Wu, G., P. Gunawardana, M.M. Bryant, R.A. Voitle and D.A. Sr. Roland, 2007. Effects of dietary energy and protein on performance, egg quality composition, egg solids, egg quality and profits of Hy-Line $\mathrm{W}-36$ hens during phase 3 . The J. of Poult. Sci., 44: 52-57.

Zeweil, S.H., A.A. Abdalah, H.M. Ahmed and R.S.A. Marwa, 2011. Effect of different 
levels of protein and methionine on performance of Baheij laying hens and environmental pollution. Egyptian. Poult. Sci., 31 (II): 621-639.
Zipp, A.J. V, K. Frankena, J. Boneschancher and B.G.M. Nieuwland, 1983. Genetic analysis of primary and secondary immune responses in the chicken. Poultry Sci., 62: $65-572$.

Table 1. Ingredients and nutrients composition of basal diets

\begin{tabular}{|c|c|c|c|}
\hline Ingredients, (\%) & Diet 1 & Diet 2 & Diet 3 \\
\hline Yellow corn & 54.00 & 58.65 & 58.60 \\
\hline Soybean meal (44\%) & 29.60 & 19.30 & 19.35 \\
\hline Wheat bran & 1.80 & 7.15 & 7.25 \\
\hline vegetable oil & 3.50 & 3.50 & 3.50 \\
\hline Di-calcium phosphate & 8.65 & 8.65 & 8.65 \\
\hline Limestone & 1.70 & 1.70 & 1.70 \\
\hline Salt $(\mathrm{NaCl})$ & 0.35 & 0.35 & 0.35 \\
\hline Vit. \& min. premix * & 0.30 & 0.30 & 0.30 \\
\hline DL-methionine & 0.10 & 0.15 & 0.05 \\
\hline L-Lysine-HCl & ----- & 0.25 & 0.25 \\
\hline Total & 100.00 & 100.00 & 100.00 \\
\hline \multicolumn{4}{|l|}{ Calculated analysis ** } \\
\hline $\mathrm{ME}(\mathrm{Kcal} / \mathrm{kg})$ & 2800 & 2800 & 2800 \\
\hline Crude protein $(\%)$ & 18.00 & 15.00 & 15.00 \\
\hline Calcium (\%) & 3.75 & 3.73 & 3.73 \\
\hline Available phosphorus (\%) & 0.45 & 0.44 & 0.44 \\
\hline Lysine (\%) & 1.02 & 1.00 & 1.00 \\
\hline Methionine (\%) & 0.40 & 0.40 & 0.30 \\
\hline Methionine + cysteine & 0.68 & 0.65 & 0.54 \\
\hline Choline (mg/kg) & 335.6 & 364.3 & 363.9 \\
\hline
\end{tabular}

Basal diet 1 (control, $18 \%$ crude protein $+0.40 \%$ methionine $+400 \mathrm{mg}$ choline $/ \mathrm{kg}$ diet).

Basal diet 2 ( $15 \%$ crude protein $+0.40 \%$ methionine $+400 \mathrm{mg}$ choline $/ \mathrm{kg}$ diet).

Basal diet 3 (15\% crude protein $+0.30 \%$ methionine $+400 \mathrm{mg}$ choline $/ \mathrm{kg}$ diet) .

* Vitamin and mineral premix at $\mathbf{0 . 3 \%}$ of the diet supplies the following per $\mathbf{K g}$ of the diet: Vitamin A 10000 I.U, Vitamin $\mathrm{D}_{3} 3000$ I.U, Vitamin E 20mg, Vitamin $\mathrm{K}_{3} 3 \mathrm{mg}$, Vitamin $\mathrm{B}_{1} 2 \mathrm{mg}$, Vitamin $\mathrm{B}_{2} 6 \mathrm{mg}$, Vitamin $\mathrm{B}_{6} 5 \mathrm{mg}$, Vitamin $\mathrm{B}_{12} 20 \mathrm{mg}$, Pantothenic acid $10 \mathrm{mg}$, Folic acid $1 \mathrm{mg}$, Biotin $5 \mathrm{mg}$, niacin $66 \mathrm{mg}$, Manganese $100 \mathrm{mg}$, Iron $100 \mathrm{mg}$, Zinc 75mg, Copper 8mg, Iodine 45mg, Selenium 10mg, Cobalt 10mg.

** According to NRC (1994). 
Table 2. Effect of experimental treatments on laying hens performance

\begin{tabular}{|c|c|c|c|c|c|c|c|}
\hline Experimental treatments & $\begin{array}{l}\text { EP } \\
(\%)\end{array}$ & $\begin{array}{c}\text { EW } \\
(\mathrm{g})\end{array}$ & $\begin{array}{c}\text { FI } \\
\text { (g/hen/day) }\end{array}$ & $\begin{array}{c}\text { PI } \\
\text { (g/hen/day) }\end{array}$ & $\begin{array}{c}\text { FCR } \\
(\mathrm{g} / \mathrm{g} \text { egg })\end{array}$ & $\begin{array}{c}\text { PCR } \\
\text { (g/g egg) }\end{array}$ & $\begin{array}{c}\text { BWG } \\
(\mathrm{g})\end{array}$ \\
\hline Control $(18 \%, 0.40 \%, 400 \mathrm{mg} / \mathrm{kg})$. & $88.84^{\text {de }}$ & $66.03^{b c}$ & $112.75^{\mathrm{e}}$ & $20.30^{\mathrm{a}}$ & $1.92^{b}$ & $0.346^{\mathrm{a}}$ & 378.00 \\
\hline T1 $(15 \%, 0.40 \%, 400 \mathrm{mg} / \mathrm{kg})$. & $87.94^{\mathrm{e}}$ & $65.53^{c}$ & $116.12^{a b}$ & $17.42^{b c}$ & $2.01^{\mathrm{a}}$ & $0.302^{b}$ & 314.56 \\
\hline T2 $(15 \%, 0.40 \%, 800 \mathrm{mg} / \mathrm{kg})$. & $90.48^{\mathrm{bc}}$ & $66.60^{a}$ & $115.23^{b c d}$ & $17.29^{\mathrm{cd}}$ & $1.91^{\mathrm{bc}}$ & $0.286^{\mathrm{c}}$ & 351.67 \\
\hline T3 $(15 \%, 0.40 \%, 1600 \mathrm{mg} / \mathrm{kg})$ & $91.59^{\mathrm{abc}}$ & $66.76^{\mathrm{a}}$ & $114.66^{\mathrm{cd}}$ & $17.20^{\mathrm{d}}$ & $1.88^{\mathrm{cd}}$ & $0.281^{\mathrm{cd}}$ & 355.00 \\
\hline $\mathrm{T} 4(15 \%, 0.30 \%, 400 \mathrm{mg} / \mathrm{kg})$. & $90.03^{\mathrm{cd}}$ & $65.76^{c}$ & $117.14^{\mathrm{a}}$ & $17.57^{\mathrm{b}}$ & $1.98^{\mathrm{a}}$ & $0.296^{\mathrm{b}}$ & 266.67 \\
\hline T5 $(15 \%, 0.30 \%, 800 \mathrm{mg} / \mathrm{kg})$. & $91.74^{\mathrm{ab}}$ & $66.50^{a b}$ & $115.52^{b c}$ & $17.33^{\mathrm{cd}}$ & $1.89^{\mathrm{bc}}$ & $0.284^{c}$ & 287.33 \\
\hline T6 $(15 \%, 0.30 \%, 1600 \mathrm{mg} / \mathrm{kg})$ & $92.93^{\mathrm{a}}$ & $66.75^{a}$ & $114.24^{\mathrm{d}}$ & $17.14^{\mathrm{d}}$ & $1.84^{\mathrm{d}}$ & $0.276^{\mathrm{d}}$ & 290.67 \\
\hline Standard error of means $( \pm \mathrm{SEM})$ & \pm 0.858 & \pm 0.289 & \pm 0.672 & \pm 0.103 & \pm 0.025 & \pm 0.039 & \pm 49.775 \\
\hline \multicolumn{8}{|l|}{ Probability } \\
\hline Protein effect & 0.043 & 0.409 & 0.0007 & $<0.0001$ & 0.932 & $<0.0001$ & 0.059 \\
\hline Methionine effect & 0.015 & 0.669 & 0.144 & 0.1422 & 0.335 & 0.0644 & 0.004 \\
\hline Choline effect & 0.019 & 0.452 & 0.455 & 0.0325 & 0.067 & 0.0007 & 0.290 \\
\hline $\begin{array}{l}\text { Protein } \mathrm{x} \text { methionine } \mathrm{x} \text { choline } \\
\text { effect }\end{array}$ & $<0.0001$ & 0.0004 & $<0.0001$ & $<0.0001$ & $<0.0001$ & $<0.0001$ & 0.119 \\
\hline
\end{tabular}

Table 3. Effect of experimental treatments on egg characteristics and immune response

\begin{tabular}{|c|c|c|c|c|c|}
\hline Experimental treatments & $\begin{array}{c}\text { ST } \\
(\mu \mathrm{m})\end{array}$ & $\begin{array}{c}\text { SW } \\
\text { (g) }\end{array}$ & $\begin{array}{c}\text { YAW } \\
\text { (g) }\end{array}$ & HU & Titre \\
\hline Control $(18 \%, 0.40 \%, 400 \mathrm{mg} / \mathrm{kg})$. & $0.383^{c}$ & 6.42 & $59.61^{\mathrm{b}}$ & 66.23 & $9.55^{\mathrm{d}}$ \\
\hline T1 $(15 \%, 0.40 \%, 400 \mathrm{mg} / \mathrm{kg})$. & $0.415^{b}$ & 6.39 & $59.14^{b}$ & 67.55 & $9.97^{\mathrm{c}}$ \\
\hline T2 (15\%, 0.40\%, $800 \mathrm{mg} / \mathrm{kg})$. & $0.438^{\mathrm{a}}$ & 6.30 & $60.31^{\mathrm{a}}$ & 67.02 & $10.00^{\mathrm{c}}$ \\
\hline T3 $(15 \%, 0.40 \%, 1600 \mathrm{mg} / \mathrm{kg})$. & $0.441^{\mathrm{a}}$ & 6.38 & $60.38^{a}$ & 67.21 & $10.07^{\mathrm{bc}}$ \\
\hline $\mathrm{T} 4(15 \%, 0.30 \%, 400 \mathrm{mg} / \mathrm{kg})$. & $0.441^{\mathrm{a}}$ & 6.49 & $59.27^{\mathrm{b}}$ & 67.22 & $9.82^{\mathrm{cd}}$ \\
\hline T5 $(15 \%, 0.30 \%, 800 \mathrm{mg} / \mathrm{kg})$. & $0.443^{\mathrm{a}}$ & 6.08 & $60.42^{\mathrm{a}}$ & 66.70 & $10.34^{\mathrm{ab}}$ \\
\hline T6 (15\%, 0.30\%, $1600 \mathrm{mg} / \mathrm{kg})$. & $0.449^{\mathrm{a}}$ & 6.25 & $60.50^{\mathrm{a}}$ & 67.04 & $10.55^{\mathrm{a}}$ \\
\hline Standard error of means $( \pm$ SEM) & \pm 0.013 & \pm 0.218 & \pm 0.298 & \pm 0.668 & \pm 0.170 \\
\hline \multicolumn{6}{|l|}{ Probability } \\
\hline Protein effect & $<0.0001$ & 0.457 & 0.457 & 0.330 & 0.004 \\
\hline Methionine effect & 0.033 & 0.321 & 0.463 & 0.960 & 0.019 \\
\hline Choline effet & 0.017 & 0.107 & 0.065 & 0.821 & 0.002 \\
\hline Protein $\mathrm{x}$ methionine $\mathrm{x}$ choline effect & 0.0002 & 0.382 & $<0.0001$ & 0.357 & $<0.0001$ \\
\hline
\end{tabular}


Table 4. Effect of experimental treatments on nutrients digestibility, nitrogen excreted and nitrogen balance

\begin{tabular}{|c|c|c|c|c|c|c|c|c|}
\hline Experimental treatments & $\begin{array}{l}\text { DM } \\
(\%)\end{array}$ & $\begin{array}{l}\text { OM } \\
(\%)\end{array}$ & $\begin{array}{l}\text { CP } \\
(\%)\end{array}$ & $\begin{array}{l}\text { EE } \\
(\%)\end{array}$ & $\begin{array}{l}\text { CF } \\
(\%)\end{array}$ & $\begin{array}{l}\text { NFE } \\
(\%)\end{array}$ & $\begin{array}{c}\text { NE } \\
\text { (g/day) }\end{array}$ & $\begin{array}{l}\text { NB } \\
(\%)\end{array}$ \\
\hline Control $(18 \%, 0.40 \%, 400 \mathrm{mg} / \mathrm{kg})$. & 68.69 & 80.47 & $96.16^{\mathrm{d}}$ & 87.41 & 26.85 & 82.33 & $1.31^{\mathrm{a}}$ & $59.81^{c}$ \\
\hline T1 $(15 \%, 0.40 \%, 400 \mathrm{mg} / \mathrm{kg})$. & 68.88 & 80.90 & $96.40^{b}$ & 88.82 & 27.14 & 82.93 & $1.06^{\mathrm{bc}}$ & $61.82^{b c}$ \\
\hline T2 $(15 \%, 0.40 \%, 800 \mathrm{mg} / \mathrm{kg})$. & 67.04 & 80.59 & $97.18^{b c}$ & 88.41 & 27.24 & 82.89 & $1.05^{\mathrm{bc}}$ & $62.04^{b}$ \\
\hline T3 $(15 \%, 0.40 \%, 1600 \mathrm{mg} / \mathrm{kg})$ & 66.70 & 80.99 & $97.08^{c}$ & 88.77 & 27.72 & 83.08 & $1.03^{\mathrm{c}}$ & $62.68^{b}$ \\
\hline T4 $(15 \%, 0.30 \%, 400 \mathrm{mg} / \mathrm{kg})$. & 67.74 & 81.42 & $98.12^{\mathrm{a}}$ & 88.58 & 27.55 & 82.95 & $1.10^{\mathrm{b}}$ & $60.88^{b c}$ \\
\hline T5 $(15 \%, 0.30 \%, 800 \mathrm{mg} / \mathrm{kg})$. & 68.84 & 81.58 & $98.21^{\mathrm{a}}$ & 88.32 & 27.58 & 82.64 & $0.90^{\mathrm{d}}$ & $67.43^{a}$ \\
\hline T6 $(15 \%, 0.30 \%, 1600 \mathrm{mg} / \mathrm{kg})$ & 69.72 & 81.70 & $98.26^{\mathrm{a}}$ & 88.83 & 27.88 & 83.26 & $0.89^{\mathrm{d}}$ & $67.69^{a}$ \\
\hline Standard error of means $( \pm$ SEM) & \pm 5.710 & \pm 0.664 & \pm 0.145 & \pm 0.223 & \pm 0.261 & \pm 0.514 & \pm 1.047 & \pm 1.162 \\
\hline \multicolumn{9}{|l|}{ Probability } \\
\hline Protein effect & 0.964 & 0.866 & $<0.0001$ & 0.085 & 0.062 & 0.813 & $<0.0001$ & 0.039 \\
\hline Methionine effect & 0.066 & 0.779 & $<0.0001$ & 0.331 & 0.120 & 0.557 & 0.0091 & 0.003 \\
\hline Choline effet & 0.126 & 0.106 & 0.039 & 0.124 & 0.702 & 0.068 & 0.0017 & 0.004 \\
\hline Protein $\mathrm{x}$ methionine $\mathrm{x}$ choline effect & 0.060 & 0.096 & $<0.0001$ & 0.126 & 0.302 & 0.442 & $<0.0001<$ & $<0.0001$ \\
\hline
\end{tabular}

Table 5. Effect of experimental treatments on economic efficiency of the experimental diets

\begin{tabular}{|c|c|c|c|c|c|c|c|}
\hline \multirow[t]{5}{*}{ Items } & \multirow{2}{*}{$\begin{array}{c}18 \% \text { CP } \\
0.40 \% \text { Met. }\end{array}$} & \multicolumn{6}{|c|}{$15 \% \mathrm{CP}$} \\
\hline & & & $0 \% \mathrm{Me}$ & & & $30 \% \mathrm{M}$ & \\
\hline & \multirow{2}{*}{$\begin{array}{c}\begin{array}{c}\text { Choline } \\
(\mathrm{mg} / \mathrm{kg})\end{array} \\
400\end{array}$} & \multicolumn{3}{|c|}{ Choline (mg/kg) } & \multicolumn{3}{|c|}{ Choline (mg/kg) } \\
\hline & & 400 & 800 & 1600 & 400 & 800 & 1600 \\
\hline & Control & T1 & $\mathbf{T} 2$ & T3 & T4 & T5 & T6 \\
\hline Price / kg feed (L.E.) ${ }^{(1)}$ & 2.45 & 2.39 & 2.39 & 2.40 & 2.35 & 2.35 & 2.36 \\
\hline Total feed intake / hen (kg) & 12.63 & 13.01 & 12.91 & 12.84 & 13.12 & 12.94 & 12.80 \\
\hline Total feed cost / hen (L.E) & 30.94 & 31.09 & 30.86 & 30.82 & 30.83 & 30.41 & 30.21 \\
\hline Total number of eggs / hen & 100 & 99 & 102 & 103 & 101 & 103 & 104 \\
\hline Price of total egg prod./ hen (L.E.) ${ }^{(2)}$ & 55.00 & 54.45 & 56.10 & 56.65 & 55.55 & 56.65 & 57.2 \\
\hline Net Revenue / hen (L.E.) ${ }^{(3)}$ & 24.06 & 23.36 & 25.24 & 25.83 & 24.72 & 26.24 & 26.99 \\
\hline Economic Efficiency (E.E.) $)^{(4)}$ & 0.78 & 0.75 & 0.82 & 0.84 & 0.80 & 0.86 & 0.89 \\
\hline Relative Economic Efficiency $(\%)^{(5)}$ & 100 & 96 & 105 & 108 & 103 & 110 & 114 \\
\hline
\end{tabular}


التأثير التعويضى للبروتين باضضافة المثيونين والكولين إلى العلائق المنخفضة البروتين على الأداء الانتاجى للاجاج البياض

إسلام إبراهيم عماره

قسم الإنتاج الحيوانس، كلية النراعة ، جامعة القاهرة

تم إجراء التجربة لدراسة التأثثر التعويضى للمثيونين والكولين فى العلائق المنخفضة البروتين على التئى الأداء الإنتاجي، وجودة

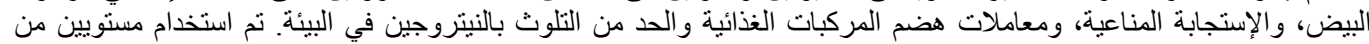

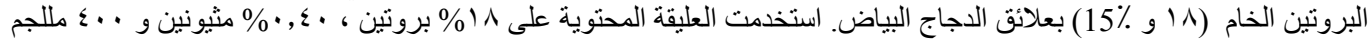

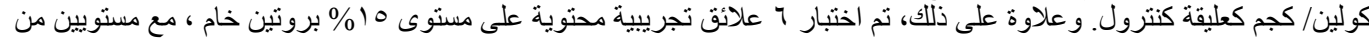

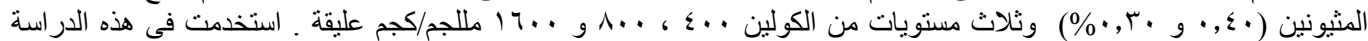

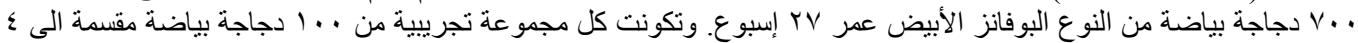

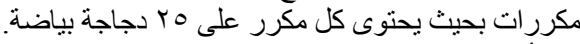

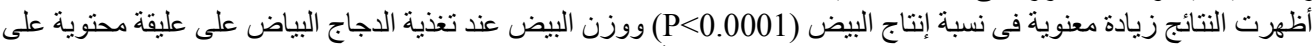

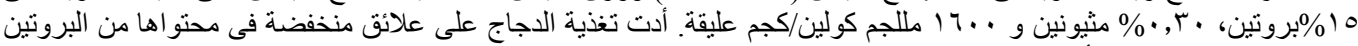

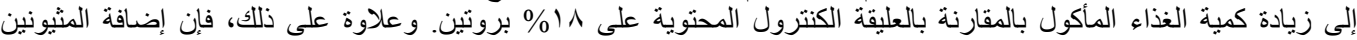

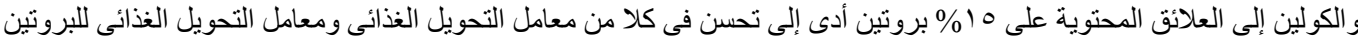

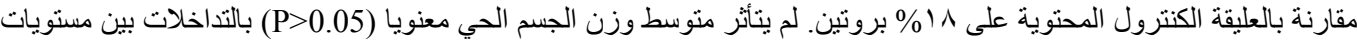

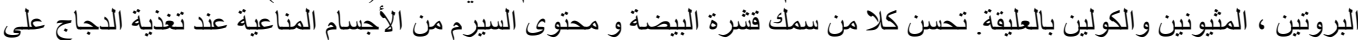

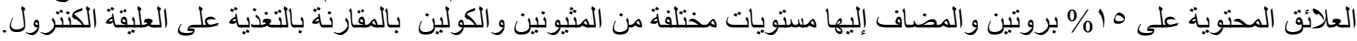

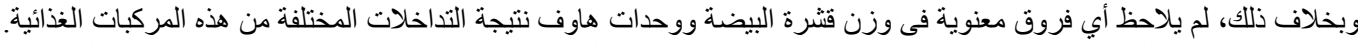

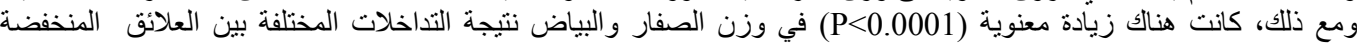

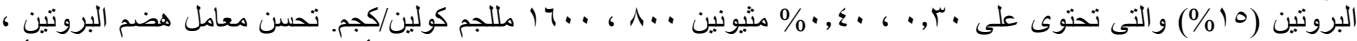

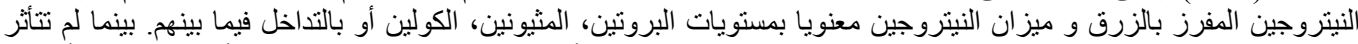

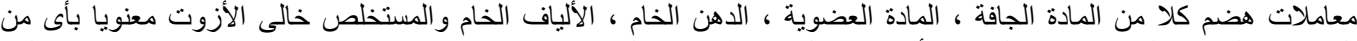

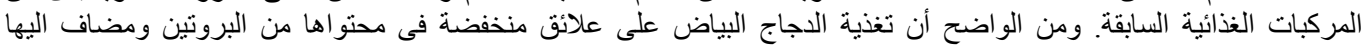

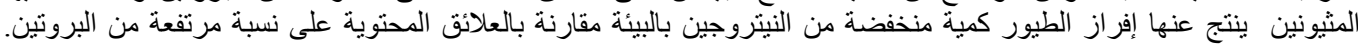

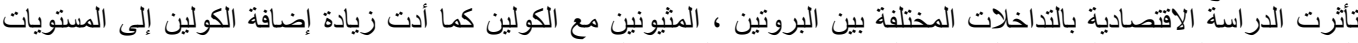

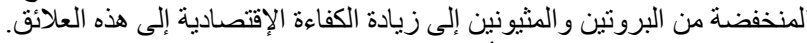

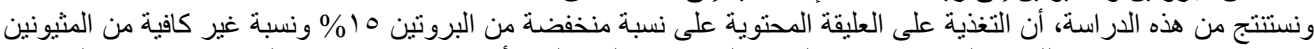

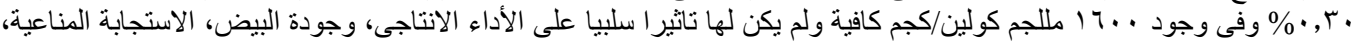

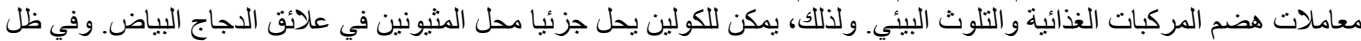

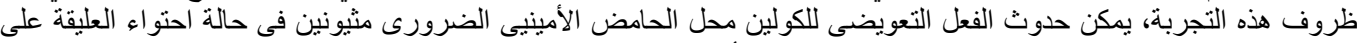

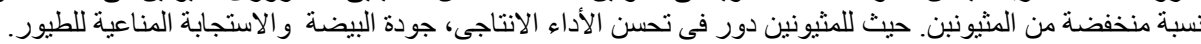

